\title{
Mapungubwe: an historical and contemporary analysis of a World Her- itage cultural landscape
}

\section{JANe CARruthers}

Carruthers, Jane. 2006. Mapungubwe: an historical and contemporary analysis of a World Heritage cultural landscape. Koedoe 49(1): 1-13. Pretoria. ISSN 0075-6458.

The Mapungubwe World Heritage cultural landscape, situated on the farm Greefswald at the junction of the Limpopo and Shashi rivers on the border of South Africa, Zimbabwe and Botswana, falls under the management of South African National Parks. This article presents a close examination of contemporary and historical issues around the inscription of the site and argues that the value of places is not self-evident but that significance is culturally constructed. This, as is explained here in respect of Mapungubwe, has changed over time and has been imposed by the concerns, aspirations and values of society at a specific time and within a specific context. Basic facts about Mapungubwe are provided and its importance as a contemporary economic and cultural driver is outlined. A brief history of Mapungubwe's inclusion in a national park from 1947 to 1949 is presented, as is the archaeological science that it spawned. The effect that the inscription of Mapungubwe may have on elevating South Africa's international profile and on African national pride is described.

Key words: Mapungubwe, World Heritage, cultural landscape, national park, archaeology, history.

Jane Carruthers Department of History, University of South Africa, P.O. Box 392, 0003 Unisa(carruej@unisa.ac.za).

\section{Introduction}

The inscription of a World Heritage Site is generally greeted with considerable publicity and expressions of national pride and selfcongratulation. While this may have palled a little for some countries that have been involved in the process since the inception of the World Heritage Convention in 1972, the excitement is still very real in South Africa. Having been barred for years from many UNESCO projects on account of apartheid, in 1997 the South African government was able to ratify the World Heritage Convention and thus became eligible to nominate sites for the list.

The legislation governing South African World Heritage Sites is the World Heritage Convention Act No. 49 of 1999.

No site is ipso facto culturally or environmentally valuable. 'A place is neither automatic nor self-evident. Places have to be made both imaginatively and materially'
(Hofmeyr 1989: 263). The aim of this article is to interrogate against the grain some of these imaginative and material values that, over time and within context, have together constructed the 'cultural landscape' of Mapungubwe, a World Heritage Site in northern Limpopo Province, South Africa. The trajectory from scientific discovery to World Heritage value is contextual and, I argue, explains much about changing linkages between South African society and the natural and cultural environment. The twentieth century history of Mapungubwe requires remembering in all its complexity. Too often heritage sites present sanitised versions of the past because the ease of an oversimplified story is so alluring.

The Mapungubwe Cultural Landscape, situated in savanna country at the point at which South Africa, Zimbabwe and Botswana converge at the confluence of the Limpopo and Shashi rivers, was added to the list of World Heritage sites in July 2003 at a meeting held 
at UNESCO headquarters in Paris. Mapungubwe itself is a high $(30 \mathrm{~m})$ isolated sandstone outcrop, some $323 \times 78 \mathrm{~m}$ in extent that overlooks the confluence. Its geographical position is significant because some seven hundred years ago Mapungubwe straddled the trade routes both to the Indian Ocean and into the interior. The underlying importance of Mapungubwe, which was abandoned after 400 years of settlement in $1290 \mathrm{AD}$, is that it was for a period the largest 'kingdom'-to use a Eurocentric term - in the sub-continent. Unlike many other precolonial sites, it is frozen in time, its remains are almost untouched and the whole place (there are other sites in the vicinity) bears witness to the development and altering landscape of complex social and political structures.

The World Heritage Committee defines cultural and natural criteria to which nominated sites must conform in order to be eligible for inscription onto the world list. Cultural landscapes, however, are a later inclusion into World Heritage. In October 1992, after years of discussion, the Operational Guidelines of the convention were revised to include this new category that represented 'the combined works of nature and man' that were of 'outstanding universal value' as specified in Article 1 of the World Heritage Convention. As far as Mapungubwe is concerned, four of the five possible cultural criteria apply, viz., criteria (ii), (iii), (iv) and (v). It also meets Article 39 of the Operational Guidelines of the World Heritage Convention, falling into the category of an 'organically evolved landscape' and the sub-categories of (ii) 'a relict (or fossil) landscape in which an evolutionary process came to an end at some time in the past, either abruptly or over a period. Its significant distinguishing features are, however, still visible in material form' and (iii) an 'associative cultural landscape ... by virtue of the powerful religious, artistic and cultural associations of the natural elements of the landscape rather than material cultural evidence, which may be insignificant or even absent', as specified in paragraphs 35 to 42 of the Operational Guidelines. Mapungubwe was South Africa's first cultural land- scape and its fifth World Heritage Site of which (at March 2006) there are seven.

\section{Discussion}

\section{Mapungubwe: basic facts}

There are more than four hundred documented archaeological sites in the vicinity of Mapungubwe. During the period 9001300 AD there were three dense settlements around Mapungubwe and each of these has yielded considerable information about the economy and society of this region. The first major centre was on the farm Schroda. This Zhizo settlement (900-1020 AD) was followed by a site that archaeologists refer to as $\mathrm{K} 2$, an extensive midden deposit of the Leopard's Kopje stylistic cluster which is quite separate from the Zhizo ceramic tradition (1020-1220 AD) and not a continuation of it (Maggs 2000:18). Mapungubwe, the hill about a kilometre to the northeast of K2, was inhabited between 1220 and $1290 \mathrm{AD}$ and it is here that the first consequences of wealth accumulation become evident. This inequitable distribution of wealth resulted in class distinction and disparity in access to resources, together with the physical separation of commoners from the ruling class or 'sacred leadership', the latter living on the top of the hill, the commoners below and serving their interests. When Mapungubwe was suddenly abandoned, the result of a combination of factors including the onset of the 'Little Ice Age' and perhaps a strong El Niño (O’Connor \& Kiker 2004: 49-66), the centre of regional power shifted to Great Zimbabwe between 1290 and 1450 AD and then to Khami (Rozwi) from 1450 to 1820 AD, both of which were inscribed on the list of World Heritage sites in 1986.

\section{Mapungubwe: a contemporary ecomonic and cultural driver}

At Mapungubwe, there is no ongoing relationship between people and place. No modern community occupies the site or can lay 
claim to an organic association with it. No oral evidence survives about the rise or abandonment of the sites during the period 900 to 1300 AD. Mapungubwe celebrates an African, but nonetheless an alien, culture for modern black and white South Africans alike. It is therefore, and unusually, a spiritually and culturally uncontested landscape, in this regard not unlike another South African World Heritage site, the far older hominid fossil deposit at the Cradle of Humankind near Johannesburg. Mapungubwe's symbolism can be appropriated by a number of groups and interested parties and the fact that it can be shared by many stakeholders means that it can serve as an exemplar landscape for South African reconciliation and nationbuilding. It can also be utilised for presentday political and economic outcomes and serve a number of contemporary agendas quite unrelated to its original function.

The most urgent of these agendas is economic development. Mapungubwe holds the promise of considerable practical benefit for expanding the tourist industry and the accompanying developmental infrastructure into the Limpopo valley, one of the more remote parts of South Africa. A number of tourist amenities are planned and interpretive visitor centres are being built inside the protected area that has recently been renamed the Mapungubwe National Park. A stairway enables visitors to climb Mapungubwe to see the 'royal' quarters and to enjoy what is a spectacular view of three countries. There is a shop and view site at the confluence of the Limpopo and Shashi rivers, and a canopylevel boardwalk in the riverine trees along the Limpopo provides views and opportunities for birding and botanizing (Norton 2000; SiVEST 2002; DEAT 2002).

David Lowenthal believes that it is inherent in modern heritage sites to become major sources of employment and revenue alike. Eco-tourism and cultural travel are increasingly conjoined' (Lowenthal 2005: 82). Among the legal requirements for South African World Heritage Sites is the obligation that they encourage investment and job creation and promote the development of culturally, environmentally and economically sustainable projects, while facilitating the empowerment and advancement of historically disadvantaged persons.

World Heritage status thus encourages the commodification of heritage but it also feeds into national pride and cohesion around 'special places' (Marschall 2005: 103-122). The status of Mapungubwe as being of world value is useful to South Africa because the resources of Limpopo Province are extremely limited and it will need substantial marketing and education in order to become attractive to the average international tourist or even to South Africans. First, the site cannot be understood without substantial interpretation. Second, getting to Mapungubwe takes effort, as it is a long drive from any metropolitan area, the climate is tropical and often extremely hot and malaria is a threat. Substantial investment will be required in order to promote and publicize the destination (Norton 2000; SiVEST 2002; DEAT 2002).

The Mapungubwe Cultural Landscape specifically elevates the profile of Limpopo Province and is already being actively used to give that province a distinct and marketable identity. There is a 'Mapungubwe Tourism Initiative' and a prominent Limpopo provincial leader, Romokone Moloto, has asserted that 'Limpopo is the home of Mapungubwe, the home of civilization' http://www.anc.org.za/limpopo/ anclimpopo.html 8 July 2005).

An annual Mapungubwe Arts Festival has been launched in Polokwane and politicians declared the inaugural event 'a resounding success that showcased many of Limpopo's talents and succeeded in attracting the best artists from all over South Africa and the continent. This festival has clearly put Limpopo [Province] on the arts and cultural map of our continent' (www.limpopo.gov.za/ dynamic/news/view/Speech1.asp?SpeechID $=218$ July 2005)

To have a World Heritage Site that can facilitate these schemes, and attribute them to Mapungubwe, is politically and ideological- 
ly useful in promoting the image of Limpopo Province.

\section{Mapungubwe: repositioning South Africa within Africa}

The South African government is anxious to project itself as a stable modern developing nation, worthy of global respect. South Africa plays the leading role in the African Union (AU) and also devised and heads up the New Partnership for African Development (NEPAD), a continental economic initiative that stands for good governance and neo-liberal economic management. In furthering this image of South African political and economic modernity and global outreach, Mapungubwe is an appropriate symbol because it salutes an early modern, technologically advanced state and economy that existed in the region long before the era of colonization. In common with modern South Africa, therefore, Mapungubwe had a commercial system with ramifications worldwide. The values encapsulated in this cultural landscape are modern, capitalistic and international.

While this jargon might seem strange to use for a site that is precolonial, integral to the agenda of the AU and NEPAD is the intellectual component of the African Renaissance. "The term "African Renaissance" carries great resonance, but for historians and archaeologists the question will inevitably arise: what was the original African "Golden Age" that will inspire the Renaissance- the rebirth of society and culture-in the new millennium? The European Renaissance, emerging out of the "dark" Middle Ages, invoked as its vision the "Golden Age" drawn from the classical cultures of Greece and Rome. What is it that southern Africa can call upon in the postcolonial era to serve as an appropriate model from the past?' The simple answer, according to archaeologist Tim Maggs, is Mapungubwe (Maggs 2000:4). This is reflected also in the symbolism projected by the Order of Mapungubwe, a national decoration that recognizes excellence in science and creativity. Of this,
Mapungubwe is an indigenous example. Its claim to technological brilliance is the indigenous production of wrought gold, ironically an industry generally much maligned in South African history because its demand for cheap unskilled labour meant a level of coercion that played the major role in the disintegration of traditional African community structures and the consolidation of racial segregation.

In May 2005 the South African Mint launched a new gold coin (a hippopotamus) in the 'Natura', 'Giants of Africa' series. Symbolically, this was done near Mapungubwe on a property belonging to De Beers, the company that operates Venetia, an opencast diamond mine in the area. Once vilified by anti-apartheid activists, De Beers has become a partner with the government in the Mapungubwe enterprise because the lucrative mine is critical for its contribution to Limpopo Province's economy and employs around 760 people (http://www.miningweekly.co.za $/ \mathrm{min} / \mathrm{sector} / \mathrm{diamonds} /$ ?show $=6$ 9276 Creamer's Media Mining Weekly 20 July 2005).

Modern South Africa is replete with paradoxes and some of them take form around Mapungubwe. Before coming to power in 1994 the policies of the African National Congress, the Congress of South African Trade Unions and the South African Communist Party were based on a vision of a classless society, entrenching workers' rights and instituting an anti-capitalist programme of nationalisation. Some rhetoric of this kind remains despite the introduction of GEAR (Growth, Employment and Redistribution) and government policy certainly aims to try to reduce the gap between rich and poor. But as explained, technology, mining, international trade, environmental and human exploitation and capitalist accumulation are integral to the cultural landscape that is World Heritage Mapungubwe. There is some irony, therefore, in the fact that Mapungubwe is celebrated as an example of early, indigenous evidence of class distinction in southern Africa. This class division did not come about because one intruding communi- 
ty came to dominate another, it was an organic outgrowth of Mapungubwe society emanating from the inequitable control over resources by the few who consolidated and expanded their power over others (Huffman 2000: 20-27). This cultural landscape therefore celebrates the emergence of a society with a hierarchy based on wealth and class and moreover, one that erased or assimilated the culture of another.

\section{Mapungubwe: cultural imperialism}

Mapungubwe does not commemorate a firstnation culture or one with an integral attachment to the landscape as a source of spirituality such as the San/Bushman hunter-gatherers of the uKhahlamba-Drakensberg, another South African World Heritage Site - a mixed site combining natural and cultural criteria. Mapungubwe is an example of one culture suppressing and supplanting another: farmers squeezing out herders and foragers. In contrast to Mapungubwe's hierarchical and class-based society and the emphasis on material accumulation, the small, kin-based San communities of the area were egalitarian and bonds between people were predicated on a strong sharing ethic and on a spiritual life characterised by shamans and trance expressed in rock paintings and engravings (Lewis-Williams 1981; 1989; 2002). Prior to the rise of Mapungubwe and its associated sites, the Limpopo area was inhabited by forager groups whose legacy is reflected in the rich rock art of the area. Another economy, that of the herders who preceded the farmers, traders and miners of the Mapungubwe 'golden age', also left its mark. The complicated relations among these groups in the area have been explored by Simon Hall and Ben Smith (Hall \& Smith 2000) and Karim Sadr (Sadr 2005). The evidence from the archaeological record is that the accomplishments of the society that is celebrated in the Mapungubwe Cultural Landscape had a range of negative implications for foragers. Despite farmers expropriating rock shelters 'by overwriting, adding to and subtracting from, and recycling huntergatherer deposits and images by imposing their own set of marks ... [Farmers] assimilated their powerful places at a general level but, at the same time, expunged and rewrote the meaning and power of place in their own terms'. Foragers were 'displaced, out-competed and marginalised as the density of farmer settlements and their social and economic complexity increased' (Hall \& Smith 2000:30-31). By the time that Mapungubwe collapsed in around $1300 \mathrm{AD}$ conventional forager identity had been erased from the region.

After Mapungubwe was suddenly abandoned, its nine thousand inhabitants scattered and mingled with other Iron Age cultures. Thereafter, changing climatic conditions left the Limpopo valley sparsely populated but the region continued to be a corridor for human movement. Groups such as the Tlokwa and Birwa are known to have passed back and forth and over time, fragments of these communities settled in the environs of Mapungubwe. The colonial frontier in this region opened with a trickle of frontiersmen. First was the arrival of the Buys people from the Eastern Cape in the 1820 s, and they soon became embroiled in local Venda contest for power. Once the Voortrekkers arrived in the late 1830 s the balance of power shifted again. The northern Boer Zoutpansberg Republic, with its capital at Schoemansdal, was dominated by elephant hunting and the export of many tons of ivory each year. In due course, settler power consolidated in the area in the late nineteenth century.

After the South African War (1899-1902) a series of generous land settlement schemes began, but because of the rugged nature of the country and its deleterious climate most farms were owned by absentee landlords or for speculative purposes by mining and land companies. In the 1930s Leo Fouché was able to describe the region as 'perhaps the wildest and most desolate in the Transvaal. The farms for the most part were unoccupied and only used for a few weeks shooting in the winter' (Fouché 1937: 1). Eventually the extension of the railway line to Musina and the burgeoning copper industry there (also a 
precolonial mining site) brought a degree of prosperity to the district but the drought and depression of the 1930s shattered the stabilising economy.

\section{Mapungubwe: a colonial adventure story}

The rigid and bureaucratic criteria of the nomination procedures for World Heritage status are unable to incorporate fully the complexity of the layers of cultural interest around Mapungubwe. One of the narratives that is omitted concerns early European perceptions of Africa and Africans that mythologized the continent as replete with superstitious and barbaric practices, peopled by people who were backward or primitive. Until the 1920s there was a general reluctance among Europeans to acknowledge that the complex walled sites such as Great Zimbabwe and others between the Limpopo and the Zambezi rivers might have been constructed by Africans. Phoenicians, Romans, Hebrews, Dravidian Indians and other outsiders were all credited from time to time with their construction. Only with British archaeologist Gertrude Caton-Thompson's work on Zimbabwe in the late 1920s were indigenous Africans eventually rightly acknowledged as the creators of these marvellous works (Caton-Thompson1931; 1939).

As explained, in the 1920s the Limpopo valley on the South African side consisted of private land, farms each of about 3000 ha that had been sold on extremely favourable terms by the state. The Van Graan family were settlers and young J.C.O. van Graan was a student at the University of Pretoria. At home on vacation in 1932 Van Graan was hunting on a neighbouring farm. The day was hot and the young man was thirsty and went looking for water. At a nearby African homestead he was offered water in an interesting ceramic container. Being intrigued by the unusual characteristics of the bowl, Van Graan offered to buy it. The owner refused to part with it but did, however, divulge that it had come from a 'sacred hill' not far way (Fouché, 1937: 1-10). His interest piqued,
Van Graan later returned with his father, E.S.J. van Graan, and three other local men intent on solving the matter of the interesting container. In trespassing on the farm Greefswald, the Van Graan party commandeered an African, named only 'Mowena' in the record, to point out Mapungubwe, the 'sacred hill'. It seems first by cajoling and subsequently by threatening and bribing, the man-'literally shivering with fright' (Fouché 1937: 1) —eventually nodded in the direction of where they should look for the route that gave access to the summit. In the narrow crevice that provided a difficult climb, a large rock fig gave some purchase.

The first to ascend was the young Van Graan. Although terrified of falling into the abyss below and frightened by bats that flew into his face, he realised that a stairway had been deliberately carved into the rock. Soon the group was atop Mapungubwe where they found golden objects in profusion-beads, bangles - and many thousands of ceramic and glass beads and pots and potsherds. As they dug around and disturbed the surface they found more and more. Eventually they realised the extent of what they had discovered and, inevitably, discussion ensued about what should be done. While the Van Graans felt guilty about their grave-robbing and some responsibility to alert the authorities, the others argued for keeping the treasure to themselves. In an interview done during the mid-1980s when he was then an elderly man, Van Graan recalled 'I then threatened to go to the police ... Things were getting really ugly. My father also pleaded: We don't have the right to these treasures ... It belongs to history ... South Africa's prehistory' (Van der Merwe 1984: 18-37).

\section{Mapungubwe: a prism of South African archaeology}

The catalyst for the academic study of Mapungubwe was Leo Fouché, Van Graan's history teacher, to whom the student had told his story. At the time, Fouché was a founder member of what had become the University of Pretoria and its Professor of History. 
Unusually for this period he taught precolonial as well as settler history and he believed that archaeology (in which he was well read and relatively expert) had much to tell about the South African past. Thoroughly bilingual but English-speaking rather than Afrikaans, he was a great friend and admirer of Jan Smuts and had been Smuts's personal secretary in 1914. Once Fouché had visited Mapungubwe he appreciated the significance of what had been discovered. Fouché arranged that the Van Graans and their neighbours be paid out for the gold objects and these were donated to the University. The professor also located E.E. Collins, the absentee owner of the farm Greefswald, and negotiated for the government to purchase it. Politicians of both parties of the time acted quickly. Given his well known and well established scientific interests, opposition leader Jan Smuts, Fouché's friend, was extremely supportive. At a meeting of the South African Association for the Advancement of Science in 1932, Smuts observed that archaeological science was 'a great field awaiting investigation in South Africa'. In 1933 he personally visited Mapungubwe (Mason 1989:107-8) and the site was the major reason for the establishment of a South African Archaeological Survey (Fouché 1937: 5).

Mapungubwe was announced internationally in the Illustrated London News of 8 April 1933. The first scientific publication relating to the site was an article that year in the South African Journal of Science entitled 'Trade and mining in the pre-European Transvaal' by F.R. Paver. The author discussed the 'remarkable grave' on the farm Greefswald that directed attention to the 'older native history of the Transvaal' that was extremely valuable and interesting. Paver expressed a keenness to hear what the archaeologists would discover and looked forward to the time when facts would replace speculation (Paver 1933: 603-611; Van Riet Lowe 1936: 282-291).

The first archaeological team under the leadership of Fouché arrived at Mapungubwe in April 1933. Soon they were joined by local
Africans who helped with the manual labour. Archaeological understanding of the time was limited, the experts differed in their interpretations and the underlying dynamics of the place eluded them. The concept of a southern African Iron Age did not then exist and most archaeological work had been done on Stone Age sites. Fouché concluded that this was a cultural site of the local community and in his book (published 1937) he even included a photograph of a man in tattered clothes labelled as 'Petty Chief Tshiwana, successor and reputed descendant of the legendary chief, Mapungubwe.' After Fouché left, the dig was led by Rhodesian archaeologist Dr Neville Jones and second series of excavations in the 1930s was conducted by Captain Guy Gardner whose monumental work was published only in 1963.

Institutional politics played a large part in the archaeological history of Mapungubwe and more detailed research in this regard would be rewarding. Between his adopting the site for his University and the publication of the Mapungubwe volumes, Fouche had resigned from the University of Pretoria in the most unpleasant of circumstances - he was hounded out for his 'liberal' and 'antiAfrikaner' views - and had taken up a post at the University of the Witwatersrand. During the 1930s the University of Pretoria increasingly came into the grip of the cultural and political values of Afrikaner Nationalism, an ideology that led to full-blown apartheid in 1948. In 1932 the language policy of the University became exclusively Afrikaans with an avowed mission to enter 'the service of the Afrikaner volk and ... to pursue the ideals of the Voortrekkers'. Academic freedom became impossible and only the heroes of Afrikanerdom were studied and revered. A culture of intolerance took hold and those who were not politically and ethnically correct-like Fouché-were victimised (Mouton 1993; University of Pretoria 1960). The discipline of History became the Afrikaner battleground and, not surprisingly in the paradigm of Afrikaner Nationalism and the 'myth of the empty land', Mapungubwe was political anathema. Because in Fouché's time there was no Department of Archaeolo- 
gy, the Professor was responsible for the establishment of an Archaeological Committee that operated between1933 to 1947. Thereafter, however, Archaeology was incorporated into a new department of Anthropology (known as Volkekunde in Afrikaans). This is a questionable discipline in South Africa because of the racism that Volkekunde espoused in its 'scientific' support for atomizing African communities into 'ethnic' groups and thus relegating them to Bantustans in terms of apartheid policy.

In the nomination document for World Heritage Status, a University of Pretoria Professor of Archaeology is quoted as saying that the slow pace of research at Mapungubwe can be explained by the lack of trained archaeologists (DEAT 2002: 21). To some extent this is entirely correct, but there is little evidence that the University of Pretoria went substantially out of its way in the early decades of working the site - this despite the fact that the excavations had deeply 'stirred the pubic imagination' (Mason 1962: 25) to prioritize the Mapungubwe dig or to bring it within South African national consciousness. This might have been accomplished, for example, by incorporating knowledge of the site (scanty as it might have been at this time) into school textbooks and the public literature as is being done today. In this regard, one might compare the high international profile enjoyed by Great Zimbabwe at this time. Moreover, because at the time they regarded their discipline as one remote from modern society, most archaeologists in South Africa distanced themselves and their work from the public domain and the question is moot as to whether any other South African academic institution, perhaps one with a tradition of liberalism or Marxism, would have done any more to publicize Mapungubwe and create public value and national pride around it. Shepherd argues that archaeology has a 'history of political implication' and has created more myths than it has dispelled, but he also acknowledges that under the political patronage of Jan Smuts, 'the study of prehistory played a key role in an emergent South African national identity' (Shepherd1999; 2002:
189-209; 2003: 826-827).This was accomplished through the establishment of a Bureau of Archaeology (later the Archaeological Survey) in the Department of the Interior. Thus archaeology in the 1930s was a directly funded branch of the civil service. This national priority, however, came to an abrupt end in 1948 when Smuts was ousted as Prime Minister and when the 'settler panAfricanism and Anglophilia ... were replaced by the parochialism of Afrikaner nationalism; the strange occluded twilight of prehistory - part fantasy, part brute material artifact - was eclipsed by the narratives of Afrikaner sacred history' (Shepherd 2003: 833). With Smuts's patronage ended (he died in 1950) archaeological enthusiasm and enterprise wavered: the second Pan-African Congress in Prehistory, which was to be held in South Africa, did not take place there, and the Archaeological Survey faltered and then closed down in the early 1960s. Only after 1994 did Mapungubwe serve a national purpose. As explained in the introduction to this article, the place needed to be imaginatively created and its culture validated as nationally significant.

Apart from the archaeological politics, a comparison of Fouché's1937 work with the Goodwin volume of 2000 edited by Mary Leslie and Tim Maggs is informative about disciplinary developments in archaeology that have aided reconstruction and appreciation of Mapungubwe's regional and international significance. In the period 1920 to 1950 effort was concentrated on artifact typologies, stratigraphic context, and material sequences. Despite the fact that 'it was possible - in fact, it was entirely normal - to practise African archaeology without knowing, or wanting to know, anything about African people per se' (Shepherd 2003: 838), it is fortunate that early archaeologists had been conservative. Consequently their findings can now be reinterpreted as societal patterns and benefit from developments in cognitive archaeology (Steyn \& Nienaber 2000: 112). Radio-carbon dating made its useful mark in the 1950s and 1960s and from the 1970 s the evidence has been re-examined (Maggs 2000: 4-5). The department of 
Volkekunde at the University of Pretoria and later, the department of Archaeology that separated from it, never ceased working at Mapungubwe. There have been a number of spurts in archaeological output. The first was from 1934 until the outbreak of the Second World War. Some digging was conducted in 1953-4 and again from about 1968 (Voigt 1983: 5) to the mid-1980s (http://mapungbuwe.up.ac.za 13 December 2004). It is now well recognized thanks to this work that Mapungubwe is part of a regional development and has a place in a far larger picture that includes other stone-walled sites of the region, for example the newly celebrated Thulamela site in the Kruger National Park as well as Great Zimbabwe, Khami and the others.

\section{Mapungubwe: a protected area}

Mapungubwe is presently within a newly established national park and is part of the proposed transfrontier conservation area that is being negotiated with neighbouring Zimbabwe and Botswana. Important though these developments are, there was, however, a previous life to this protected area and it is integral to the history of Mapungubwe and national park policy in the region. It forms another layer in the cultural construction of Mapungubwe that needs to be recalled. I have written elsewhere in an article called 'Dongola Wild Life Sanctuary: "psychological blunder, economic folly and political monstrosity" or "more valuable than rubies and gold"? (Carruthers 1992) about the details of the genesis, brief existence and demise of the only substantial national park in South Africa ever to be abolished.

Few people are aware that this Limpopo valley landscape was formerly a national park with a strong cultural focus in addition to an ecological one. Nor do they know that political pressure from local white farmers and Afrikaner Nationalists keen on vote-grabbing before a general election led to its abolition. It is surprising that the Dongola Wild Life Sanctuary fell from public memory so quickly because during the period 1944 to
1949 it received wide publicity in South Africa and was known at the time as the 'Battle of Dongola'. It led to some of the longest and most acrimonious debates in the South African parliament and the largest Select Committee Report on record. In 1944 when discussion began, the Dongola Wild Life Sanctuary (named after a volcanoshaped mountain in the north-east corner of the farm Goeree) was to be a vast area of 240 000ha, stretching from five kilometres west of Musina to the confluence of the Limpopo and Macloutsie rivers, an area some $100 \mathrm{~km}$ long and $36 \mathrm{~km}$ wide at its widest point. By the time the politicians had compromised, the national park (Dongola Wild Life Sanctuary Act No. 6 of 1947) had been reduced to 92000 ha, beginning further westwards and ending not far west of the junction of the Limpopo and Shashi rivers. A far smaller protected area has been recreated in the Mapungubwe National Park and this has been at considerable expense to the state because since the 1950s irrigation in the Limpopo Valley has become feasible and there is an extensive agricultural industry by way of citrus, tomatoes and other crops.

The Dongola Wild Life Sanctuary would have been South Africa's first national park to be founded on ecological and scientific principles. Attention had been drawn to this area in the 1920s by South African botanists who were in the vanguard of the new ecological thinking that was developing in Britain. The person most responsible was Dr I.B. Pole Evans who, after an education in Wales and at Cambridge, took up the post of mycologist and plant pathologist in the Department of Agriculture in the Transvaal Colony in 1905. He was soon out of the laboratory and in the field. He initiated vegetation surveys, developed new fodder grasses, described plant species and involved himself in the broader issues of soil and vegetation conservation. Pole Evans became well acquainted and friendly with Jan Smuts, himself an amateur botanist of some stature, and thanks to the efforts of these men in 1918 the Department of Agriculture established a Botanical Survey of the Union. 
To assist the Botanical Survey a number of botanical reserves were set aside in different ecosystems of the country and one of these was in the Mapungubwe area. This block of nine farms was named the Dongola Botanical Reserve. Over the next decade, the Reserve achieved some of its objectives. Being under conservation management rather than cattle ranching, it was not long before wildlife returned to Dongola. There was soon a distinct difference between environmental conditions within and outside it, and problems of overgrazing on the neighbouring properties were soon quite clear. Because no work had been done on Mapungubwe for a number of years, in the early 1940s the government took over the farm Greefswald from the University of Pretoria and added others to the Dongola Reserve.

Pole Evans lobbied to have Dongola elevated to national park status, not so much on account of the wildlife it contained, but on the basis of the scientific value of a natural research station, the ecological knowledge that could be gained and the proximity of Mapungubwe. When Smuts became Prime Minister again in 1939 the scheme really took off and his Minister of Lands, Andrew Conroy, became a great proponent. Part of the government's plan was to collaborate with the Rhodesian government and the chartered company of Bechuanaland to create an international protected area that would straddle the Limpopo valley and have Mapungubwe as its cultural focus, much as is the plan today.

In the event, Dongola was politically divisive and highly contested. Conroy, Pole Evans and Smuts were taken aback by the animosity towards the scheme from local farmers and the opposition National Party which, hoping to come into power in 1948 , defended white property owners against expropriation. The National Parks Board, dominated as it was then by Nationalists and by the Broederbond, refused to discuss the matter. The scheme was vilified in the Afrikaner press. But undeterred and undaunted, and apparently without specifically cultivating support, Conroy went ahead, announcing his scheme in October 1944 in the Government Gazette. Because private farms were to be expropriated, a Select Committee had to be appointed.

When the matter came before Parliament, the debate was vicious and personal and the Dongola National Park was a major election issue in 1948. The fact that the international community considered this favourably was, at that time of rising South African isolationism, a negative argument not a positive one as World Heritage status is today in a different national and global environment. That black Africans might have been canvassed for their views and given the national park their support was another negative to the National Party. But when parliament voted in 1947 it was strictly on party lines and the national park was written into law. Soon trustees were appointed, money raised, farms acquired, negotiations for the transfrontier park begun, and Dongola was poised to fulfil the promise which Conroy, Smuts and Pole Evans (now warden) believed that it held.

But this was not to be. So intense were emotions over Dongola that when the National Party won the 1948 election the national park was abolished-as voters had been promised. There was a short revival of interest in re-establishing the Dongola Sanctuary in the mid 1960s by the South African Association for the Advancement of Science which sounded out the Minister of Agriculture, the National Parks Board and the University of Pretoria. From all three quarters there was a negative response, memories of the previous debacle still being too fresh although three farms became a 'reserve' in 1967.

During the 1970s and 1980s South Africa was involved in a war with its neighbouring states that harboured what were regarded by the then government as 'terrorists' intent on destabilising the country. The army built an electric fence along the Limpopo boundary and Greefswald became a place for 'rehabilitating' conscripted gays and drug offenders. Army top brass often went out hunting and 
poached the large game of the district. They even defaced local rock shelters with graffiti (Bonner \& Carruthers 2003: 8, 53). But ironically, the fact that an army detachment was based on Greefswald brought renewed attention to the site and in the 1980s both K2 and Mapungubwe Hill were declared national monuments. By the 1990s the political ground had shifted once more and to most people it had become clear that the end of apartheid was in sight. It was around this time that the Venetia Diamond Mine began operating and diamond giant De Beers established its own 26 000ha Venetia Limpopo Nature Reserve, including Schroda and bordering on Greefswald.

While recognized for its good record in wildlife conservation and management South African National Parks has, however, come in for fierce criticism because of its ethos of 'fortress conservation' that marginalized local communities and Africans in general, from the national park enterprise. SANParks can also be criticized, however, for neglecting its legal duty in terms of cultural conservation because, by law, it is obliged to value the cultural, historical and archaeological dimensions of its protected areas. The fact that Mapungubwe now lies within a national park is of obvious merit to righting the situation.

\section{Conclusion}

World Heritage consultant Peter Fowler has emphasised that the absence of any intrusion of unsympathetic development is an essential quality of a World Heritage cultural landscape (Fowler 2003). Despite the fact that the place was once the home to around nine thousand people with their cattle, agricultural fields and iron and gold smelting works the site is considered to be 'authentic' because no one lives there. (There are, however, currently a number of land restitution claims in the area and on Greefswald (SANParks 2002: 33)). Certainly the pre-colonial population at Mapungubwe altered this environment substantially, probably removing trees as well as piling tons of soil on the summit of the hill. Declaring this a World Heritage Cultural Landscape is, arguably, celebrating environmental usage which was quite unsustainable.

Lowenthal argues, as I do, that culture and nature are interconnected and indivisible (Lowenthal 2005: 81-92). Mapungubwe is not natural, but an environment constructed to reflect the society that utilised it. The driver of the original society was the use, exploitation and maximisation of natural resources to reinforce social, political and economic values. The lesson that can be drawn from Mapungubwe as a cultural landscape is the recognition that 'much of the world's terrestrial surface is, to a greater or lesser extent, "cultural landscape" [and] one of the most important long-term benefits of the inclusion of cultural landscapes under the World Heritage Convention is that it should help to promote everywhere greater awareness of landscape issues generally' (Fowler 2002). But as well as the physical landscape, the intellectual and political landscape of Mapungubwe subsequent to its abandonment needs to be remembered and integrated into its heritage values. Mapungubwe has faded out of the 'history' of the modern era twice: the first time after 1290 when it was abandoned, and the second after 1949 when it was suppressed. It has now been resurrected and transformed to meet the demands of a new society and has been given a role to play in national identity, national pride, national and transnational economics and politics.

\section{Acknowledgements}

I thank the Humanities Research Centre, The Australian National University, Canberra, and its Director, Professor Ian Donaldson, for awarding me a Visiting Fellowship in 2005 and with it the opportunity to benefit from the 'Cultural Landscape' programme. I am also grateful to the History Program of the Research School of Social Sciences at The Australian National University for previous visits to Canberra that have greatly informed my work on heritage issues. In particular I value assistance from Libby Robin, Tom Griffiths, Mandy Martin, Guy Fitzhardinge, Vincent Carruthers, Peter Norton, Phil Bonner, Richard Grove, Mike Smith, Jane Lennon, 
Kirsty Douglas, Max Bourke, John Mulvaney, Tom Huffman, Isabel McBryde, Alex Mouton, Greg Cuthbertson and Emily O'Gorman, as well as the anonymous readers of this article.

\section{References}

Bonner, P. \& E.J. CARruthers. 2003. The recent history of the Mapungubwe area. Mapungubwe Cultural Heritage Resources Survey. Unpublished report commissioned by the Department of Environmental Affairs and Tourism: Funded by the Norwegian Government.

Breedlove, G. 2003. A systematics for the South African cultural landscape with a view to implementation. Ph. D. thesis, University of Pretoria, Pretoria.

CArruthers, J. 1992. Dongola Wild Life Sanctuary: 'psychological blunder, economic folly and political monstrosity' or 'more valuable than rubies and gold'. Kleio 24: 82-100.

Carruthers, J. 2005. Wildlife science and livestock disease in South Africa, 1900 to 1960. Paper presented at the conference 'Science, disease and livestock economies' at St Antony's College, Oxford.

Caton-Thompson, G. 1939. Mapungubwe. Antiquity 13 (51): 324-341.

Caton-Thompson, G. 1931. The Zimbabwe Culture. Oxford: Clarendon Press.

DeAcon, J. 1993. Archaeological sites as national monuments in South Africa: a review of sites declared since 1936. South African Historical Journal 29: 118-131.

DEPARTMENT OF ENVIRONMENTAL AFFAIRS AND TOURISM (DEAT). 2002. Mapungubwe World Heritage Site Nomination. Pretoria: Government Printer?

FouchÉ, L. (ed.) 1937. Mapungubwe: Ancient Bantu Civilization on the Limpopo. Cambridge: University Press.

Fowler, P. 2002. World Heritage Cultural Landscapes, 1992-2002: a review and prospect, Cultural Landscapes: the Challenges of Conservation World Heritage 2002, Shared Legacy, Common Responsibility Associated Workshops 11-12 November 2002 Ferrara-Italy. http:// whc.unesco.org/venice2002.

Fowler, P. 2003. World Heritage Cultural Landscapes 1992-2002, World Heritage Papers 6, 2003. UNESCO World Heritage Centre, Paris World Heritage Cultural Landscapes 1992-2002 http://whc.unesco.org.

GARDNER, G.J. 1958. Mapungubwe and the second volume. South African Archaeological Bulletin 13: $123-132$.
GARDNER, G.J. 1955. Mapungubwe 1935-1940. South African Archaeological Bulletin 10: 73-77.

Gardner, G.J. 1963. Mapungubwe Vol. II. Pretoria: Van Schaik.

Hall, S. \& B. Smith. 2000. Empowering places: rock shelters and ritual control in farmer-forager interactions in the Northern Province. Pp. 3046. In: Leslie, M. \& T. MagGs (eds.). African Naissance: The Limpopo Valley 1000 Years Ago. Cape Town: The South African Archaeological Society. (Goodwin Series, Vol. 8.)

HofMEYR, I. 1989. Turning region into narrative: English storytelling in the Waterberg. In: BoNNER, P., I. HofmeYr, D. JAMES \& T. LOdGE (eds.). Holding their ground: Class locality and culture in 19th and 20th century South Africa. Johannesburg: Witwatersrand University Press.

Huffman, T. M. 2005. Mapungubwe: Ancient African civilisation on the Limpopo. Johannesburg: Witwatersrand University Press.

Huffman, T.M. 2000. Mapungubwe and the origins of the Zimbabwe culture. Pp.14-29. In: LESLIE, M. \& T. MagGs (eds.). African Naissance: The Limpopo Valley 1000 Years Ago. Cape Town: The South African Archaeological Society. (Goodwin Series, Vol. 8.)

Leslie, M. \& T. MagGs (eds.). 2000. African Naissance: The Limpopo Valley 1000 Years Ago. Cape Town: The South African Archaeological Society. (Goodwin Series, Vol. 8.)

LEWIS-WILliams, J.D. 2002. A cosmos in stone: Interpreting religion and society through rock art. Walnut Creek: CA, AltaMira Press.

LEWIS-Williams, J.D. 1981. Believing and seeing: Symbolic meanings in southern African San rock paintings. London: Academic Press.

LEWIS-WILliams, J.D. 1989. Images of power: Understanding Bushman rock art. Johannesburg: Southern Book Publishers.

Lowenthal, D. 2005. Natural and cultural heritage. International Journal of Heritage Studies 11(1): 81-92.

LOWENTHAL, D. 1997. The heritage crusade and the spoils of history. London: Viking.

LowenthaL, D. 1985. The past is a foreign country. Cambridge: Cambridge University Press.

Maggs, T. 2000. African Naissance: An introduction. Pp. 1-4. In: Leslie, M. \& T. MaGgs (eds.). African Naissance: The Limpopo Valley 1000 Years Ago. Cape Town: The South African Archaeological Society. (Goodwin Series, Vol. 8.)

Marschall, S. 2005. Making money with memories: The fusion of heritage, tourism and identity formation in South Africa. Historia 50(1): 103-122.

Mason, R. 1962. Prehistory of the Transvaal: a record of human activity. Johannesburg: Witwatersrand University Press. 
Mason, R.J. 1989. South African Archaeology 19221988. Johannesburg: Archaeological Research Unit University of the Witwatersrand.

Mouton, F.A. 1993. Professor Leo Fouché, the History Department and the Afrikanerisation of the University of Pretoria. Historia 38(1): 51-63.

MunJERI, D. 2002. Smart partnerships: Cultural Landscape issues in Africa, Cultural Landscapes: the Challenges of Conservation World Heritage 2002. Shared Legacy, Common Responsibility Associated Workshops 11-12 November 2002 Ferrara - Italy http://whc. unesco.org/venice2002.

Norton, P. 2000. An overview of tourism development potential in the Mapungubwe area. Johannesburg: DBSA.

O’Connor, T.G. \& G.A. KiKer. 2004. Collapse of the Mapungubwe society: vulnerability of pastoralism to increasing aridity. Climatic Change $66(1 / 2): 49-66$.

SADR, K. 2005. Hunter-gatherers and herders of the Kalahari during the late Holocene. Pp. 206-221. In: Veth, P., Sмith, M. \& P. Hiscock (eds.). Desert peoples: Archaeological perspectives. Malden: Blackwell.

SHEPHERD, N. 2003. State of the discipline: Science, culture and identity in South African archaeology, 1870-2003. Journal of Southern African Studies 29 (4): 823-844.

SHEPHERD, N. 2002. The politics of Archaeology in Africa. Annual review of Anthropology 31: 189-209.

SiVest Consortium. 2002. Mapungubwe Tourism Initiative Conceptual Tourism Destination Plan.

South African National PArks. 2002. Notes to the annual financial statements for the year ended 31 March 2002.

Steyn, M. \& W. Nienaber. 2000. Iron Age human skeletal remains from the Limpopo Valley and
Soutpansberg area. Pp. 112-116. In: Leslie, M. \& T. Maggs (eds.). African Naissance: The Limpopo Valley 1000 Years Ago. Cape Town: The South African Archaeological Society. (Goodwin Series, Vol. 8.)

UnIVERsity of Pretoria. 1960. Ad Destinatum: Gedenkboek van die Universiteit van Pretoria. Vol. 1. Johannesburg: Voortrekkerpers.

VAn Der Merwe, C. 1984. The face of South Africa -Mapungubwe. Flying Springbok June, 1984: 18-37.

VAn Riet Lowe, C. 1936. Mapungubwe: First report on excavations in the northern Transvaal. Antiquity 10(39): 282-291.

VAN WARMELO, N.J. 1942.The copper miners of Musina and the early history of the Zoutpansberg. Pretoria: Government Printer.

Voigt, E.A. 1983. Mapungbwe: An archaeological interpretation of an Iron Age community. Pretoria: Transvaal Museum Monograph No. 1.

WeINEK, C. 2000. The hills are alive: A new documentary uncovers a drama of denied heritage, stolen treasures and botched excavations. Mail and Guardian 3-9 March: 3.

World Heritage Convention. 1972. Convention Concerning the Protection of the World Cultural and Natural Heritage. Paris: UNESCO.

www.limpopo.gov.za/dynamic/news/view/Speech1. asp?SpeechID=2. Accessed 18 July 2005

http://www.anc.org.za/limpopo/anclimpopo.html Accessed 18 July 2005.

http://www.mining-technology.com/projects/ de_beers/specs.html.

http://www.miningweekly.co.za/min/sector/diamonds/?show $=69276$, Creamer's Media Mining Weekly 20 July 2005. 